\title{
Pemanfaatan Lengkuas (Alpinia galanga L. Swartz) Untuk Mengawetkan Ikan Pindang Tongkol (Euthynnus pelamis L.)
}

\section{The usage of Galangale (Alpinia galanga L. Swartz) to Preserve "Pindang" Tuna Fish (Euthynnus pelamis L.)}

\author{
Kianto Atmodjo ${ }^{*}$, Yuniarti Aida \& Mursyanti \\ Fakultas Biologi Universitas Atma Jaya Yogyakarta, Jl. Babarsari 44 Yogyakarta \\ ${ }^{*}$ Author untuk korespondesi
}

\begin{abstract}
The objective of this research was to prove that galangale rhizome (Alpinia galanga L. Swartz) can be used to preserved "pindang" tuna fish (Euthynnus pelamis L.). The fish were cooked by galangale rhizome solution (the concentration were 0, 50, 100, 150, 200 $\mathrm{mg} / \mathrm{l} \mathrm{b} / \mathrm{v}$ ) for 15 minutes. Then, the fish were stored in box, three fishes /box, and stored at room temperature for 6 days. Every day, The quality of fish were measured as colour, rubberness, taste, odor, total of bacteria and fungi. The result showed that there were decreased of the fish quality, spoilaged, and many fungi and bacteri growth after two days, and the level of spoilage of fish was influenced the increasing of galangale rhizome concentration. It concluded that the galangale rhizome can not use as "pindang" tuna fish preservative.
\end{abstract}

Key words: Galangale rhizome, preservative, "pindang” tuna fish, quality

Diterima: 16 September 2002, disetujui 14 Desember 2002

\section{Pendahuluan}

Ikan pindang merupakan salah satu produk olahan tradisional yang telah lama dikenal dan digemari masyarakat. Pemindangan bertujuan untuk mengawetkan ikan dengan cara merebus dalam larutan garam. Tingginya konsentrasi air dan gizi ikan pindang menyebabkan ikan pindang mudah mengalami proses pembusukan oleh proses autolisis dan atau mikrobia sehingga daya keawetannya rendah. Pratiwi dan Rusyanto (1997) melaporkan nilai Aw ikan pindang berkisar 0,77 sampai dengan 0,95 dan ditemukan berbagai macam jamur benang dan bakteri, sedangkan Afrianto dan Liviawaty (1989) menunjukkan bahwa konsentrasi protein ikan pindang berkisar antara 18-30\%. Wibowo (2000) menuliskan bahwa daya simpan ikan pindang hanya 2-3 hari.

Usaha untuk meningkatkan daya simpan ikan pindang selama ini memanfaatkan zat pengawet seperti sodium sorbitol atau sodium benzoat dan sodium nitrit yang sebenarnya merupakan zat yang berbahaya. Oleh karena itu perlu dicari zat pengawet alami. Salah satu di antaranya adalah lengkuas yang dipercaya mempunyai senyawa antimikrobia selain sebagai bumbu (Wibowo, 2000). Rahayu et. al. (1999) dan Pratiwi (2001) membuktikan bahwa minyak atsiri lengkuas mempunyai daya antimikrobia. Rusmarlin et. al. (1999) telah mengkaji senyawa "acetoxy chavicol acetate" (ACA) suatu senyawa fenil propanoid dalam minyak atsiri lengkuas yang berpotensi menghambat pertumbuhan sel kanker dan mikrobia.

Namun demikian, semua pembuktian daya antimikrobia lengkuas masih dalam batas penelitian laboratorium menggunakan pengekstrak berbahaya dan mahal.sedangkan dilapangan lengkuas hanya digunakan sebgai bumbu dan dilarutkan dalam air. Penelitian tentang tumbuhan obat, beberapa tanaman obat 
tersebut bila diekstrak dengan air daya toksisnya lebih tinggi dibanding dengan alkohol (Pratiwi dan Simanjuntak, 1998). Oleh karena itu, penelitian ini bertujuan untuk membuktikan apakah selain sebgaai bumbu, lengkuas juga dapat digunakan untuk meningkatkan keawetan ikan pindang.

\section{Bahan dan Cara Kerja}

\section{a. Lengkuas}

Rimpang lengkuas diperoleh dari pasar. Rimpang dipilih yang tua dan besar serta berbau paling harum. Lengkuas dikuliti dan diparut. Lengkuas ini dimasukkan ke dalam air matang dengan variasi konsentrasi 50, 100, 150, dan $200 \mathrm{~g} / \mathrm{l}$. Air lengkuas ini digunakan untuk merendam ikan pindang selama 15 menit.

\section{b. Ikan Tongkol}

Ikan tongkol dengan berat sekitar 150$200 \mathrm{~g}$ diperoleh dari tempat pelelangan ikan di Parang Kusumo Bantul, Yogyakarta. Ikan disimpan dalam kotak pendingin dan ditimbuni es batu untuk mencegah autolisis selama proses pengangkutan yang memerlukan waktu sekitar satu jam ke Laboratorium Mikrobiologi Fakultas Biologi Universitas Atma Jaya Yogyakarta.

\section{c. Pemindangan Ikan}

Ikan pindang dibuat dengan cara ikan tongkol dibersihkan dan dibuang insang dan isi perutnya. Dimasukkan dalam kukusan, ditata selapis-demi selapis. Setiap lapisan ikan ditaburi garam merata sehingga semua bagian ikan tertutup. Kemudian dididihkan selama 15 menit, dan didinginkan (Afrianto dan Liviawaty, 1994).

\section{d. Pengawetan Ikan Pindang dengan Lengkuas}

Ikan pindang yang diperoleh direndam dalam air lengkuas $(0,50,100,150$, dan 200 g/l) pada suhu sekitar $40^{\circ} \mathrm{C}$ selama 15 menit, kemudian ditiriskan, dimasukkan dan disimpan dalam suhu kamar. Penyimpanan menggunakan besek yang telah disterilkan terlebih dahulu. Tiap besek berisi 3 ekor ikan.

\section{e. Keawetan Ikan Pindang}

Keawetan ikan pindang ini diukur dengan cara membandingkan morfologi (warna, bau, rasa dan kekenyalan) dan total mikrobia. Semakin bagus morfologinya dan semakin rendah total mikrobianya semakin bagus dan awet ikan pindang tersebut. Keawetan ikan ini diamati setiap hari selama enam hari.

\section{f. Morfologi}

Morfologi ikan yang diamati adalah warna, bau, rasa, kekerasan/kekenyalan, dan ada tidak lendir berdasarkan uji organoleptik yang melibatkan 20orang. Tiap parameter diskor dengan angka 1-5. Semakin besar skornya menunjukkan semakin baik morfologinya.

\section{g. Total Mikrobia}

Mikrobia yang dihitung adalah jamur dan bakteri. Sebanyak satu g daging ikan pindang dimasukkan ke dalam $9 \mathrm{ml}$ air steril. Digojog selama satu menit. Diencerkan sampai diperoleh pengenceran $10^{3-5}$. Sebanyak $0,1 \mathrm{ml}$ pengenceran ini dimasukkan ke dalam petri dan dituangi medium nutrien agar sebanyak 10 ml untuk menumbuhkan bakteri. Pekerjaan yang sama diulang tetapi dituangi medium potato dektrosa agar untuk menumbuhkan jamur.

\section{h. Rancangan Penelitian dan Analisis Data}

Penelitian ini dirancang menggunakan rancangan acak lengkap dengan lima aras perlakuan konsentrasi lengkuas dan 3 ulangan. Data yang diperoleh dianalasis varian .

\section{i. Waktu dan Tempat penelitian}

Penelitian ini dilakukan mulai Mei 2001 sampai dengan Juni 2002, di laboratorium Mikrobiologi Fakultas Biologi Universitas Atma Jaya Yogyakarta. 


\section{Hasil dan Pembahasan}

Ikan pindang sebagai salah satu bentuk hasil olahan ikan segar yang direbus dalam air garam yang cepat menurun mutunya. Keawetan atau daya simpan ikan pindang biasanya berkisar antara 2-3 hari (Afrianto dan Liviawaty, 1989), sedangkan menurut Yanto, seorang produsen ikan pindang di Yogyakarta, daya simpan ikan pindang hanya 1 hari untuk ikan pindang biasa, dan 2 hari untuk ikan pindang presto.

Untuk melihat mutu ikan pindang banyak parameter yang harus dilihat, Wibowo (2000), menyebutkan ada empat parameter untuk mengenal mutu ikan pindang dengan cepat dan mudah yaitu mofofologi berupa rupa dan warna, bau, rasa dan tekstur/kekenyalan/elastisitas. Selain itu untuk lebih meyakinkan perlu adanya pemeriksaan biokimia dan atau mikrobiologis.

\section{a. Warna}

Ikan pindang yang diawetkan dengan air lengkuas pada berbagai konsentrasi menunjukkan hasil yang tidak berbeda nyata (tabel 1). Warna ikan pindang relatif tidak berubah, tetap seperti ikan segar. Hal ini memperlihatkan bahwa meskipun air lengkuas berwarna hijau kekuningan karena adanya kurkumin dan kristal kuning (Muhlizah, 1999) namun tidak mengubah warna ikan.

Perubahan warna ikan, justru terjadi setelah ikan disimpan lebih dari dua hari. Warna ikan menjadi agak kuning-coklat berupa bercak-bercak. Diperkirakan warna ini timbul dikarenakan adanya proses oksidasi fenol yang semakin lama semakin besar. Hal ini diperlihatkan bahwa warna yang ditimbulkan semakin lama semakin banyak. Selain itu ada warna lain seperti hitam, coklat, dan hijau setelah penyimpanan di atas 3 hari. Warna ini ditimbulkan olah spora jamur yang tumbuh.

Ada hal yang menarik dari perubahan warna yang terjadi dari ikan pindang ini. Pada ikan pindang yang diperlakukan dengan lengkuas, semakin tinggi konsentrasi lengkuasnya, semakin cepat dan semakin nyata perubahan warnanya. Ini berarti perlakuan dengan lengkuas tidak mengubah warna ikan pindang segar, namun memacu perubahan warna setelah disimpan.

\section{b. Kekenyalan}

Kekenyalan ikan pindang yang dimaksud adalah mudah tidaknya ikan ini ditusuk dengan jarum, mudah tidaknya daging ikan diiris, mudah tidaknya daging ikan dilepas. Hasil penelitian ini memperlihatkan bahwa kekenyalan ikan pindang baru (hari O) antara yang dierlakukan dengan lengkuas dan tanpa lengkuas tidak beda. Demikian pula antar perlakuan lengkuas tidak menunjukkan beda nyata, kenyal tetapi tidak terlalu kenyal atau keras (tabel 1). Sebagai tambahan hasil, selain kenyal, daging ikan nya juga cukup kuat dan tidak mudah diiris dan tidak mudah disuwir. Ini menunjukkan ikan pindang bermutu baik (Wibowo,2000).

Kekenyalan ikan pindang menurun seiring dengan semakin lama penyimpanan. Pola penurunan kekenyalan mirip antar perlakuan,.yaitu mulai menurun setelah disimpan 2 hari, dan menjadi lembek setelah disimpan 4-5 hari. Pada ikan pindang yang diperlakukan dengan lengkuas konsentrasi 100$200 \mathrm{mg} / \mathrm{l}$ ada kecenderungan lebih cepat menurun kekenyalannya.

Penurunan kekenyalan ikan pindang ini dikarenakan adanya proses pemutusan ikatan kimia molekul tinggi menjadi molekul kecil dan pemecahan jaringan oleh nadanya proses enzimatis, oksidasi dan serangan mikrobia (Afrianto dan Liviawaty, 1989). Ini berarti perlakuan lengkuas tidak mempengaruhi hasil ikan pindang segar, namun memacu proses pemecahan molekul dan jaringan.

\section{c. Rasa}

Rasa ikan pindang yang baik adalah gurih spesifik pindang, enak, tidak terlalu asin, rasa asin merata, dan tidak ada rasa asing (Wibowo, 2000). Hasil penelitian ini diperoleh rasa ikan pindang yang diberi perlakuan lengkuas pada konsentrasi di bawah $100 \mathrm{~g} / \mathrm{l}$ sama dengan yang tidak diberi perlakuan, sedangkan yang diberi perlakuan di atas $100 \mathrm{~g} / \mathrm{l}$ terasa rasa lengkuas.

Perubahan rasa ikan pindang setelah disimpan selama enam hari, baru terasa setelah 
disimpan 2 hari (Tabel 2). Rasa yang diperoleh adalah rasa agak masam, pahit dan agak tengik yang kontinyu. Perubahan rasa ini lebih terasa pada ikan pindang yang diberi perlakuan lengkuas, dan semakin tinggi konsentrasinya semakin kuat rasanya. Ini berarti perlakuan lengkuas memacu perubahan rasa. Adapun perubahan rasa ini terjadi akibat reaksi biokimia yang menghasilkan senyawa fenol dan quinon yang terjadi pada proses pembusukan, pada ikan pindang ini dikenal proses rigor mortis (Afrianto dan Liviawaty, 1989). Lengkuas mengandung minyak atsiri yang terdiri atas senyawa fenol yang mampu memacu pembentuk senyawa fenol lain. Selain itu juga minyak atsiri lengkuas juga mengandung asam lemak tidak jenuh yang mudah teroksidasi dan menimbulkan rasa tengik (Rahayu et al., 1999).

\section{d. Bau}

Bau awal ikan pindang yang dibuat adalah spesifik seperti bau ikan rebus, gurih, dan segar. Bau terasa pada ikan pindang tanpa perlakuan lengkuas dan dengan perlakuan lengkuas sampai konsentrasi $100 \mathrm{~g} / \mathrm{l}$. Pada ikan pindang yang diperlakukan dengan lengkuas konsentrasi 150 dan $200 \mathrm{~g} / \mathrm{l}$ bau yang timbul terasa sedikit bau lengkuas. Hal ini wajar dan sering terjadi demikian pada pemanfaatan empon-empon untuk bumbu, apa bila berlebih akan terasa bau khas empon-empon tersebut ((Muhlisah, 1999). Bau khas empon-empon, termasuk lengkuas ditentukan oleh konsentrasi minyak atsiri dan senyawa penyusunnya (Pratiwi, 2001).

Bau segar ikan pindang dan lengkuas tersebut akan berkurang (tabel 2) setelah disimpan 2 hari, berganti bau anyir dan busuk. Pada perlakuan dengan lengkuas, terutama konsentrasi di atas $100 \mathrm{~g} / \mathrm{l}$ perubahan bau ini lebih cepat. Seperti diketahui bau yang terjadi dikarenakan adanya proses autolisispembusukan sendiri oleh enzim ikan pindang maupun serangan mikrobia. Ini berarti perlakuan dengan lengkuas justru memacu proses autolisis tersebut. Hal ini didukung oleh penelitian Pratiwi (2001) yang menunjukkan bahwa beberapa minyak atsiri empon-empon mampu merangsang proses kimia tubuh dan tidak membunuh mikrobia.

\section{e. Bakteri}

Hasil pemanatauan bakteri yang tumbuh pada ikan pindang yang diperlakukan dengan lengkuas tertera pada Tabel 3. Sebagai tambahan informasi data diketahui juga bahwa warna koloni bakteri yang tumbuh ada 3 macam yaitu putih, merah dan kuning, namun pada penelitian ini belum dilakukan identifikasi.

Pada hari pertama tidak dijumpai adanya bakteri, ini menunjukkan bahwa ikan pindang pada semua perlakuan telah memenuhi persyaratan, (Wibowo, 2000). Bakteri mulai muncul pada hari kedua, juga pada semua perlakuan dan kontrol, dan semakin lama penyimpanan semakin banyak bakteri yang tumbuh. Selain itu, pertumbuhan bakteri berkaitan dengan peningkatan konsentrasi lengkuas. Menurut Afrianto dan Liviawty (1989) bakteri yang tumbuh di sini berasal dari ikannya sendiri, bumbu dalam hal ini lengkuas, besek tempat penyimpanan, garam, dan ruangan.

Adanya pertumbuhan bakteri ini membuktikan bahwa penambahan lengkuas pada pembuatan ikan pindang, hanya sekedar bumbu untuk menambah rasa, tetapi tidak untuk mengawetkan (Muhlisah, 2000). Selain itu banyaknya bakteri pada konsentrasi lengkuas tinggi membuktikan bahwa zat katif dalam larutan lengkuas tersebut justru memacu pertumbuhan bakteri. Ini mungkin dikarenakan proses pemanasan pada pembuatan ikan pindang telah menghilangkan minyak atsiri lengkuas (Pratiwi, 2001). Menurut Rusmailin et al (1999) dan Rahayu (1999) senyawa ACA salah satu komponen minyak atsiri lengkuas yang berperan sebagai antimikrobia bersifat mudah hilang karena pemanasan. Di sisi lain pelarutan dan pemanasan air lengkuas akan lebih memacu komponen karbohidrat dan protein yang akan menjadi bahan nutrien yang baik bagi pertumbuhan bakteri (Wibowo, 2000). 


\section{f. Jamur.}

Pertumbuhan jamur pada ikan pindang yang diperlakukan dengan lengkuas polanya tidak jauh beda dengan bakteri (Tabel 3). Perbedaan yang utama adalah pertumbuhan jamur lebih lambat sehari dibanding bakteri. Sebagai tambahan data hasil, jamur yang dijumpai ada 4 strain, yaitu strain dengan warna spora hijau, hitam, coklat keemasan, serta putih. Menurut Afrianto dan liviawaty (1989) dan diperkuat oleh Rahayu et al (1999) jamur yang banyak tumbuh pada ikan pindang adalah genus Rhizopus dan Aspergillus.

Hasil di atas yang secara keseluruhan menunjukkan ketidakmampuan lengkuas untuk menjaga mutu ikan pindang dapat dimengerti. Ini dikarenakan lengkuas yang digunakan sebagai bumbu ikan pindang, pemberiannya hanya langsung ditambahkan pada saat perendaman atau perebusan. Zat yang akan masuk ke dalam ikan pindang adalah zat yang larut air dan yang tidak menguap karena pemanasan. Zat tersebut di antaranya adalah karbohidrat, protein, vitamin dan mineral yang akan memacu timbulnya mikrobia bakteri dan jamur. Padahal Zat aktif antimikrobia pada lengkuas, yaitu ACA merupakan zat yang tak larut dalam air, namun larut dalam hekasana, klorofom atau eter (Pratiwi, 2001; Rusmarilin, 1999; Rahayu, 1999) yang tidak mungkin diaplikasikan untuk pembuatan ikan pindang. Hasil penelitian dari Pratiwi dan Simanjuntak (1998) yang melaporkan bahwa daya toksis terhadap mikrobia beberapa tumbuhan obat pada pelarutan air lebih tinggi dibanding kloroform dan alkohol tidak berlaku pada penelitian ini.

\section{Kesimpulan}

Berdasarkan hasil dan uraian di atas maka dapat disimpulkan perendaman ikan pindang tongkol dalam air lengkuas tidak dapat mengawetkan atau memperlama umur simpan ikan pindang. Semakin besar konsentrasi lengkuas yang digunakan semakin besar tingkat penurunan kualitas ikan pindang.

\section{Ucapan terimakasih}

Ucapan terima kasih pertama-tama disampaikan kepada Universitas Atma Jaya Yogyakarta yang telah memberikan kesempatan dan dana untuk membiayai penelitian ini, kedua kepada Dr Djagal W. Marseno yang telah membimbing penelitian ini, dan ketiga kepada Bapak Yanto, produsen ikan pindang Yogyakarta yang telah membantu dan memberi informasi tentang pemindangan.

\section{Daftar Pustaka}

Afrianto E. dan E. Liviawaty. 1989. Pengawetan dan Pengolahan Ikan. Kanisius, Yogyakarta

Muhlisah F., 1999. Teтu-temuan dan Emponempon: Budidaya dan Manfaatnya. Kanisius. Yogyakarta

Parwati T. dan P. Simanjuntak. 1998. Daya Toksis Beberapa Tumbuhan Obat Tradisional Indonesia Asal Nusa Tenggara Barat. J. Biologi Ind. II (3) : 118-125.

Pratiwi S.T., 2001. Uji Daya Anti Jamur Minyak Atsiri Beberapa Species Suku Zingiberaceae. Pharmacon. II. 2:46-50

Rahayu W.P., 1999. Aktivitas Antimikrobia Lengkuas (Alpinia galanga L. Swartz), Pros. Sem. Nas. Makanan Tradisional.

Rahayu W.P., S. Ferdiaz, B.S.L. Jenie, B. Satiawihardja, A. Apriyantono, dan L.K. Darusaman. 1999. Ektraksi Dan Fraksinasi Komponen Antimikrobia Dari rimpang Lengkuas (Alpinia galangan L. Swartz.). Pros. Sem. Nas. Teknologi Pangan

Rusmailin, H., H. Astawa dan D. Muchtadi. 1999. Kajian terhadap Karakteristik Ekstrak Rimpang Lengkuas (Alpinia galanga (L) Sw.) dengan menggunakan Kloroform. Pros. Sem. Nas. Teknologi Pangan

Wibowo S., 2000. Industri Pemindangan Ikan. Panebar Swadaya. Jakarta 
Tabel 1. Morfologi warna dan kekerasan ikan pindang yang diawetkan dengan lengkuas

\begin{tabular}{cllllllllllll}
\hline & \multicolumn{10}{c}{ Hari } & \multicolumn{10}{c}{0} & \multicolumn{10}{c}{50} & \multicolumn{1}{c}{100} & \multicolumn{1}{c}{150} & \multicolumn{2}{c}{200} \\
\cline { 2 - 12 } & W & K & W & K & W & K & W & K & W & K \\
\hline \hline I & 5 & 4,3 & 5 & 4,5 & 5 & 4,5 & 5 & 4,3 & 5 & 4,3 \\
II & 4,4 & 4,3 & 4,3 & 4,4 & 4,2 & 4,3 & 4,3 & 4,2 & 4,3 & 4,3 \\
III & 4,1 & 3,4 & 4,2 & 3,5 & 3,5 & 3,3 & 3,4 & 3,5 & 3,6 & 3,4 \\
IV & 3,5 & 2,9 & 3,7 & 3,3 & 3,6 & 2,7 & 3,2 & 2,6 & 3,2 & 2,6 \\
V & 3,4 & 2,6 & 3,4 & 2,6 & 3,2 & 2,5 & 3,2 & 2,6 & 3,1 & 2,5 \\
VI & 3,3 & 2,5 & 3,4 & 2,5 & 3,2 & 2,3 & 3,1 & 2,4 & 3,1 & 2,2 \\
\hline
\end{tabular}

Keterangan :

a. Kriteria warna tetap (skor 5), sedikit berubah (skor 4), berubah ( skor 3), sangat berubah (skor 2), amat sangat berubah (skor 1)

b. Kriteria kekenyalan = sangat kenyal (skor 5), kenyal (skor 4), sedang ( 3), lembek (skor 2), sangat lembek (skor 1)

Tabel 2. Rasa $(R)$ dan bau $(B)$ ikan pindang yang diawetkan dengan lengkuas

\begin{tabular}{llllllllllll}
\hline & \multicolumn{10}{c}{ Konsentrasi Lengkuas g/l } \\
\cline { 2 - 12 } & \multicolumn{2}{c}{ Hari } & \multicolumn{10}{c}{50} & \multicolumn{1}{c}{100} & & 150 & \multicolumn{2}{c}{200} \\
\cline { 2 - 12 } & R & B & R & B & R & B & R & B & R & B \\
\hline \hline I & 5 & 5 & 5 & 5 & 5 & 4,4 & 5 & 4,3 & 5 & 4,2 \\
II & 4,4 & 5 & 5 & 5 & 5 & 4,2 & 5 & 4,2 & 5 & 4,2 \\
III & 3,4 & 3,5 & 5 & 5 & 4,3 & 4,0 & 4,1 & 4,1 & 4,2 & 3,2 \\
IV & 2,5 & 2,5 & 4,6 & 3,4 & 3,3 & 2,8 & 3,6 & 3,2 & 3,3 & 2,7 \\
V & 2,5 & 2,2 & 3,5 & 3,3 & 3,1 & 2,8 & 2,2 & 2,4 & 2,2 & 2,2 \\
VI & 2,1 & 2,0 & 2,2 & 3,1 & 2,7 & 2,2 & 1,9 & 2,0 & 1,5 & 2,0 \\
\hline
\end{tabular}

Keterangan :

a. Kriteria perubahan rasa khas ikan pindang = tetap+disukai (skor 5), sedikit berubah +disukai(skor 4), berubah +agak disukai ( skor 3), sangat berubah + tidak disukai (skor 2), amat sangat berubah +sangat tidak disukai (skor 1)

b. Kriteria bau= tidak berbau/bau khas pindang (skor 5), bau lengkuas (4), bau tidak enak(3), bau busuk (2), sangat busuk (1)

Tabel 3. Total mikrobia jamur $(J)$ dan bakteri $(B)$ ikan pindang yang diawetkan dengan lengkuas

\begin{tabular}{|c|c|c|c|c|c|c|c|c|c|c|}
\hline \multirow{3}{*}{ Hari } & \multicolumn{10}{|c|}{ Konsentrasi Lengkuas g/l } \\
\hline & \multicolumn{2}{|c|}{0} & \multicolumn{2}{|c|}{50} & \multicolumn{2}{|c|}{100} & \multicolumn{2}{|c|}{150} & \multicolumn{2}{|c|}{200} \\
\hline & $\mathrm{J}$ & $\mathrm{B}$ & $\mathrm{J}$ & $\mathrm{B}$ & $\mathrm{J}$ & $\mathrm{B}$ & $\mathrm{J}$ & B & $\mathrm{J}$ & B \\
\hline I & 0 & 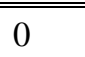 & 0 & 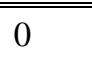 & 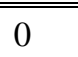 & 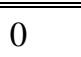 & 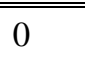 & 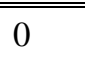 & 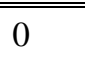 & 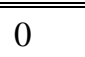 \\
\hline II & 0 & 3,21 & 0 & 2,6 & 0 & 6,7 & 0 & 6,6 & 0 & 8,8 \\
\hline III & 2,4 & 15,1 & 4,5 & $18 ., 2$ & 5,3 & 25,1 & 3,4 & 37,2 & 7,6 & 55,3 \\
\hline IV & 5,3 & 20,3 & 4.7 & 22,1 & 7,7 & $\mathrm{Sp}$ & 8,6 & $\mathrm{Sp}$ & 8,8 & $\mathrm{Sp}$ \\
\hline V & 8,5 & $\mathrm{Sp}$ & 7.2 & $\mathrm{Sp}$ & 9,2 & $\mathrm{Sp}$ & 14,3 & $\mathrm{Sp}$ & 17,2 & $\mathrm{Sp}$ \\
\hline VI & $\mathrm{Sp}$ & $\mathrm{Sp}$ & $\mathrm{Sp}$ & $\mathrm{Sp}$ & $\mathrm{Sp}$ & $\mathrm{Sp}$ & $\mathrm{Sp}$ & $\mathrm{Sp}$ & $\mathrm{Sp}$ & $\mathrm{Sp}$ \\
\hline
\end{tabular}

Keterangan :

1. Angka dalam tabel bersatuan $10^{6} \mathrm{sel} / \mathrm{g}$ ikan

2. Huruf Sp menunjukkan cacahnya sangat melimpah / tak terhitung. 